\title{
Chemical Castration for Pedophile Perpetrators- Expectation and Implementation Reviewed from Medical-Juridical Aspects
}

\author{
Setyo Sugiharto $^{1}$, Fifik Wiryani ${ }^{2}$, Muhamad Nasser ${ }^{3}$ \\ (setyo.sugiharto77@gmail.com ${ }^{1}$, fwiryani2016@gmail.com², nasserkelly@yahoo.com³ \\ ${ }^{1,2,3}$ Graduate Programs, Faculty of Law, Universitas Muhammadiyah Malang, \\ Jl. Raya Tlogomas No. 246, 65144, Malang, Indonesia
}

\begin{abstract}
Panel of judges in Mojokerto District Court handed down the verdict on Aris. He was sentenced to 12 years imprisonment,and chemical castration as additional sentence, a lively debate about chemical castration sentences emerged in between the pros and cons community. Government and the House of Representatives are supportive party, since they representing people who feel uneasy due to the increasing cases of pedophilia in every year. In their opinion, chemical castration provides a deterrent effect, thus no more victims were violated. On the other hand, human rights activists disagree on chemical castration since it violates human rights. Moreover, castration legal basis which regulated in Article 81 Paragraph (6) and Paragraph (7) of 2016 Law Number 17, concerning the Establishment of Government Regulations in Law Number 1 of 2016 replacement,concerning Child Protection, has drawn protests on its implementation. Doctor association also stated that the doctor who executes chemical castration is violating medical ethics code and the doctor's oath. This study is expected to open up insights on what penalties should be received by pedophiles.
\end{abstract}

Keywords: Castration, Pedophilia Preparators, Medical.

\section{Introduction}

There has been an increase in cases of sexual violence against children in recent years, even there are victims who were killed. From the several pedophile cases that occur, the perpetrators were from the victim's neighborhood. Including from the family, the environment around the child, their home, school, educational institution, or social environment [1]. Sexual violence often occurs in children because they are always positioned as a figure who is weak or helpless and have a high dependency with the adults around them. Threat makes children helpless, and they could not tell their experiences to others. Based on the evaluation of pedophile perpetrators and violence cases against children revealed, the perpetrator is someone who is close to the victim or people who have domination against the victim. There are no specific characteristics or personalities to identify sexual violence perpetrator against children or pedophilia. Sexual violence against children are including acts, showing media/pornographic objects, showing genitals to children's, touching, kissing sexual children organs, rape, and even persecution and murder [2].

The Law no. 23 year 2002 on Child Protection defines a child as a person who is still in the womb until an age under 18. Pedophilia perpetrators do sexual violence against children to get sexual pleasure or satisfaction from the victim [3]. 
Based on their identity, sexual perpetrators are divided into two, namely [4]:

a. Familial Abuse

A blood relationship exists between the victim and the perpetrator and the perpetrator is part of the main family member. Including parents, stepfathers, caregivers or someone who is trusted to care for the children.

b. Extra Familial Abuse

Sexual violence perpetrators are outside the victim's family. Usually, the offender is a person who has been known by the victim and has established relations with the child, then entices the child into a situation where the sexual harassment may commit. Often lured by giving certain rewards that are not obtained at home. Since the victim is afraid of being scolded by the parents, usually the child does not dare to report. So the parents must care for children's playmates and behavioral change.

Forensic psychologist Reza Indragiri Amriel divides pedophile into 2 types [5]:

1. Exclusive Pedophilia, which only has an interest in children.

2. Facultative Pedophilia, which has heterosexual orientation in adults, but prefers to choose children as substitution/impingement.

Actions that categorized as sexual violence against children are: touching the child's body, whether the child wears clothes or not; all forms of sex penetration, including penetration into the child's mouth using objects or limbs; make or force a child to engage in sexual activity; intentionally engaging in sexual activity in the presence of a child, or not protecting and preventing the child from witnessing sexual activity by another person; create, distribute, and display images or films containing scenes of children in indecent poses or actions; and showing children, pictures, photos or films that show sexual activity can be considered sexual abuse of children [6]. To uncover the existence of sexual violence against children is not easy, because sexual violence tends to have a traumatic impact on children. They feel pressured to not reporting sexual violence and find it difficult to trust other people to keep their sexual violence a secret. It is because they feel threatened and obtain worse consequences when reporting and feel ashamed. They also feel that the incidents occurred because of their mistakes. Sexual violence also makes feel that they are embarrassing the family name [7]. Some of the impacts arising from sexual violence against children including [8]:

1. Biological impact before puberty.

Children's vital organs are not prepared for intercourse. If forced, these actions will damage the organ's tissue.

2. Psychological/social impact.

Since the perpetrators do not want their actions known, they will intimidate the victims to keep it as a secret. The victims may experience psychological depression and withdrawal from their social relationships.

Basic punishments for pedophilia are imprisonment and fines. If the action is repeated, causing disability and death will charge several additional penalties. The names of the perpetrators would be announced in public or they will get castration chemical punishment. Generally, castration is distinguished into two categories. First, surgery castration involves cutting the sperm duct, so that sperm will be unable to flow. Second, chemical castration is done by injecting chemicals named anti-androgen drugs into a person's body. The substances contained in this drug are expected to reduce testosterone production. So that, the perpetrators will experience sexual drive loss. Drugs often used to suppress testosterone production are medroxyprogesterone acetate, cyproterone, and leuprorelin [9]. For men, testosterone hormone may arouse libido. So if the hormone is reduced, then sex drive will be reduced, apart from 
testosterone hormone sex drive can also be due to previous sexual experience, health conditions, psychological factors, and sexual organ function. Therefore, even if people are given anti-testosterone drugs, the desire for sexual relations will not necessarily disappear altogether [10]. Besides to suppress sexual desire, anti-testosterone drug injection may cause complex side effects, such as decreased muscle strength, osteoporosis, anemia, increased fat, decreased cognitive function, and triggering a heart attack. Men experience infertility because they do not have spermatozoa cells. The effects of anti-testosterone drugs are also temporary, so the sexual arousal can reappear if the drug is stopped [11].

The implementation of chemical castration as additional punishment on pedophilia is still in debate, due to viewpoints differences in addressing the problem. Groups who supported chemical castration argued that this action was needed to give a deterrent effect on pedophilie perpetrators, so repeated actions will not happen. On the other side, groups that oppose the action assume that chemical castration violates human rights. Medical teams that will perform chemical castration also disagree with this punishment [12-15].

\section{Core Problems}

Proposed problem in this paper is:

1. How is the application of article 81 paragraph 7 of law number 17 of 2016 against pedophiles?

\section{Research Method}

This is normative research with legislation approach by examining the principles of law, legal norms, rules, and regulations from laws, documents, books, and other relevant official sources. The description result was discussed, analyzed using theories, opinions from the perspective of law and medical experts combined with the researcher's opinion. The purpose was conclude to answer the issues raised in the study.

The primary legal materials used in this research included castration legal basis which regulated in Article 81 Paragraph (6) and Paragraph (7) of 2016 Law Number 17, concerning the Establishment of Government Regulations in Law Number 1 of 2016 replacement, concerning the Second Amendment to Law Number 23 of 2002.

The secondary legal materials included: journals, papers, relevant studies, books, documents, and legal writings. The tertiary legal materials included law dictionary, EnglishIndonesian dictionary, encyclopedia, and related data.

\section{Discussion}

Pedophilia is a type of crime against children that has long been happening in society. The culprit is called a pedophile, adult humans who have deviant sexual behavior. Pedophilia as a mental disorder means making children as the object or target of the action sexually [16]. Pedophilia is not only a behavior but also a defiant attitude as the tendency of liking children for adult sexual satisfaction [17].

Some factors causing pedophilia including [18]:

1. History of traumatic events

A prior victim that experienced trauma has learned that sexual satisfaction can be obtained from children. 
2. Lack of socialization

An introvert or closed person will have an inability to build relationships with children's environment.

3. Low Self-Esteem

People who feel that they don't have any strengths or failure compared to their partner or friends. They probably have mental disorders, depression, and anxiety that are very difficult to forget.

Sexual violence level that occurs to the children divided into several categories [19]:

1. Action related to sexual stimulation including sexual interaction, non-coitus, petting, fondling, exhibitionism, and voyeurism.

2. Rape or sexual assault, including oral or genital penetration, masturbation, oral stimulation of the penis (fellatio), and oral stimulation of the clitoris (cunnilingus).

3. The most fatal action is called forced rape. There are even several murder cases to the victims.

Some of the effects of sexual abuse on children are [20]:

1. Emotional

As a victim of sexual violence, children experience stress, depression, mental turmoil, feelings of guilt and self-blame, fear of others, memories of the incident, nightmares, insomnia, self-esteem problems, sexual dysfunction, addiction, and suicidal thoughts.

2. Physical

Children's bodies are still growing and physically not as strong as adults. Thus, the damage in their body could be worse than in an adult's body.

Based on the National Commission on Women's Protection and the Indonesian Child Protection Commission's report, in last decade there has been an increase in sexual violence against children. The government considers the increase of these incidents are due to ineffective punishment to the offenders, so that deterrent effect has not happened. As nation's successors, children must be protected by giving the pedophiles appropriate punishment thus they will not repeat their actions. Therefore, through the Parliament Law No. 17 of 2016, in Article 81 paragraph 7, the government agreed to perform chemical castration as additional punishment toward pedophilia perpetrators. Due to debate and several rejections on the law, the implementation was not that easy. The medical team who expected to perform chemical castration also refused the idea, as well as human rights activists [21].

Chemical castration is defined as injection of anti-testosterone substances to a man's body, through injection or oral to decreasing testosterone hormones level to reduce sexual desire. This hormone is mostly produced by leydig cells in the testicles and has a huge role in man's sexual function, namely sexual arousal and erection. By injecting anti-testosterone drugs, the offender is expected to lose their sexual drive [22]. Another side effect from this medicine is decreased muscle strength, bone loss, anemia, increased blood lipid levels, decreased cognitive function, affect the heart and blood vessels has the potential to cause infertility because it may block spermatozoa cells production [23]. Unfortunately, antitestosterone drugs neutralizers could be easily found in the market. The drug effects are also temporary, so sexual arousal can reappear if the drug is stopped [24].

Another problem faced is the Indonesian Doctors Association (IDI) clearly refusing to perform chemical castration due to the contrary to the doctor's oath and medical ethics violation. "Based on the scientific evidence, chemical castration does not guarantee the sexual desire disappearance or decreasing preparator's potential sexual violence behavior." said IDI Chairperson of the Medical Professional Development Council (MPPK), Pudjo Hartono. He 
officially stated that appointing the doctor as chemical castration executor was against the Honorary Council and Medical Ethics (MKEK) Number 1 of 2016 concerning Chemical Castration as well as Indonesian Medical Ethics Code [25,26]. Even though medically chemical castration may decrease sex drive, the social, and psychological impact on the castrated person must be studied deeply. Thus, during and after serving his sentence, the preparators can get psychological and social assistance [27].

Chemical castration as a punishment is violating human rights. Thus, human rights organizations reject it under several reasons, namely [28]:

1. Castration as a punishment is not justified by the national criminal law system or criminal purpose followed by Indonesian legal system.

2. Castration punishment violates human rights as stated in various international conventions that have been ratified in our national law. Including the Covenant on Civil and Political Rights (ICCPR), Convention Against Torture (CAT), and also the Convention on Rights of the Child (CRC). In any form, corporal punishment is interpreted as torture and acts that degrading human dignity, especially if it is intended as retaliation.

Even though the main reason is scientific doubt on the deterrent effect.

3. Every form of violence against children, including sexual violence, is basically a desire manifestation to control and dominate children. The castration law does not place violence against children as the main problem. Therefore, human rights organizations are asking the government's consideration to focus on children's interests comprehensively.

Based on the arguments above, it is clear that there are pros and cons in implementing castration chemical punishment with pedophile preparator's approval. It is necessary to find the best punishment which gives deterrent effect to them so that sexual violence against children will not reoccur.

\section{Conclusion}

The implementation of Act 81 Paragraph 7 of Law Number 17 Year 2016 concerning pedophile perpetrators has several drawbacks. Namely, the drug's negative effect is unequal with the impact. In addition, due to breaking doctor oaths and medical ethics, Indonesian Doctor's Association rejected becoming a chemical castration executor. Chemical castration also does not obtain legal certainty yet in Indonesian Law.

\section{Suggestion}

It is suggested that the perpetrators are given a choice between chemical castration or another additional punishment which still needs to be formulated. A careful assessment must be made before imposing chemical castration punishment, particularly in the preparator's hormonal disorder. If there are no hormonal abnormalities found, then another form of punishment is suggested. Educating executors who came from non-medical backgrounds is also necessary. Special training and improving executor competencies to perform chemical castration is needed.

\section{References}


[1] Indanah, "Sexual Abuse in Children", Journal of Nursing and Midwifery, vol. 7, no. 1 , page. 16-23, 2016.

[2] D. Sommaliagustina dan D. C. Sari, Sexual Abuse Towards Children In Human Rights Perspective", Psychopolytan (Journal of Psychology), vol. 1, no. 2, page 76-85, 2018.

[3] Law Number 35 of 2014 on Child Protection, Cell, vol. 3, no. 4, page 1-15, 2014.

[4] V. Septiani, "Indonesia Emergency Sexual Harassment: Case Law Enforcement," 2018.

[5] Pi. Noviana, "Child Sexual Abuse: Its Effects and Handling," Sosio Inf., vol. 1, no. 1, page. 13-28, 2019.

[6] N. Rohmah, K. Novitasari, dan U. D. H, "Relationship Between Perpetrators, Victims and Vulnerability in Children," page. 5-10, 2017.

[7] A. Sulisyowati, "Prevent Violence Against Children," vol. 06, no. 01, page. 17-27, 2018.

[8] U. Zahirah, N. Nurwati, dan H. Krisnani, "Impact and Handling of Child Sexual Violence in the Family," Proceeding of Research and Community Service., vol. 6, no. 1, page 10, 2019.

[9] A. A. Firmanto, "Position of Castration in Indonesia Criminal System (After the issuance of Government Regulation in Lieu of Law No. 1 of 2016)," J. Huk. Nov., vol. 8, no. 1, page. 1, 2017.

[10] A. Naufal, "What Is Chemical Castration," Journal of Knowledge Management, vol. 2 , no. 2, page. $1-18,2019$.

[11] A. naufal Dzulfaroh, "Castration Punishment from The Discourse of Government Regulation in Lieu of Law,” no. 20, page. 5-10, 2019.

[12] N. Q. Mardiya, "Implementation of Chemical Castration for Sexual Violence Preparator," J. Konstitusi, vol. 14, no. 1, page. 18, 2017.

[13] B. Friandy et al., "Sanctions From Chemical Castration," Implement. Sci., vol. 39, no. 1, page. 1-15, 2014.

[14] Krismiyarsi, "Castration Chemical Sanction Policy For Sexual Violence Preparator Against Children-Political Study of Criminal Law," National Seminar of Law Universitas Negeri Semarang, vol. 4, no. 1, page. 92, 2018.

[15] N. Wisnu, "Castrated Verdict, Aris Became The First Preparator," 2019.

[16] M. Ruhma dan E. A. Setiowati, "Knowledge of Pedophilia and Anxiety Against Sexual Violence for Parents with Children with Special Needs," vol. 12, no. 2, page. 5967, 2017.

[17] S. Hikmah, M. Ibtidaiyah, dan M. I. Grobogan, "I Dare To Protect Myself ": Study at the al-Hikmah Foundation Grobogan, Abstract," vol. 12, no. April, page. 187-206, 2017.

[18] M. Tedja, "Socio-economic Conditions And Sexual Violence Against Children," vol. VIII, no. 09, 2018.

[19] P. Wahyu Agustina dan A. Kusumaning Ratri, "Analysis of Sexual Violence in Elementary School Children," Journal of Educational Theory and Practice Studies, vol. 3, no. 2, page. 151-155, 2018.

[20] P. Hairi, "Problem of Sexual Violence: Examining the Direction of Government Policy in Countermeasures," Negara Hukum, vol. 6, no. 1, page. 1-16, 2015.

[21] A. Labanta, "Effectiveness of castration chemical sanctions in the prevention of sexual crimes against children in the Special Region of Yogyakarta," 2017.

[22] Anindya, "Understanding Chemical Castration," Journal of Chemistry Inf. Model., vol. 53, no. 9, page. 1689-1699, 2019. 
[23] N. Claudia, "Chemical Castration," $A \gamma \alpha \pi \eta$, vol. 8, no. 5, page. 55, 2019.

[24] Nickey Aulia, "Chemical Castration Implementation," Journal of Chemistry Inf. Model., vol. 53, no. 9, page. 1689-1699, 2019.

[25] A. Mahyani and A. Yuriswanto, "Castration as Additional Punishment," Journal of Untag.Sby.Ac.Id, vol. 14, page. 28-40, 2018.

[26] S. Soetedjo, J. Sundoro, dan A. Sulaiman, "Doctor's Ethics Review as the Castration Executor,” Journal of Etika Kedokteran Indonesia, vol. 2, no. 2, page. 67, 2018.

[27] S. Wuryani, "Deterrent Effect of Chemical Castration for Preparator of Child Sexual Violence from Psychological Perspective," 2019.

[28] A. Trimaya, "Observing the Regulation of Castration Punishment in Indonesia," Journal of RechtsVinding Online, 2016. 